Journal of Clinical Investigation

Vol. 42, No. 6,1963

\title{
EFFECTS OF BILE SALTS ON GLUCOSE METABOLISM BY SLICES OF HAMSTER SMALL INTESTINE *
}

\author{
By PETER R. HOLT, $\dagger$ HERBERT A. HAESSLER, AND KURT J. ISSELBACHER
}

(From the Department of Medicine, Harvard Medical School, and the Medical Services [Gastrointestinal Unit], Massachusetts General Hospital, Boston, Mass.)

(Submitted for publication September 14, 1962; accepted February 13, 1963)

Bile salts are known to be essential for the effective absorption of fat from the intestinal tract (1). They have been shown to stimulate the action of pancreatic lipase (2) and have an important emulsifying action on water-insoluble dietary triglycerides that is probably related to their ability to form micelles with fatty acids and monoglycerides (3). In addition to their role in triglyceride absorption, bile salts also appear to be essential in the absorption and esterification of vitamin A (4) and cholesterol (5).

In previous studies from this laboratory (6), it was shown that conjugated bile salts enhanced the esterification of palmitate-C $\mathrm{C}^{14}$ to triglycerides and appeared to stimulate the incorporation of glucose- $\mathrm{C}^{14}$ into glyceride-glycerol. These observations suggested that in the intestinal mucosa, bile salts influence the metabolism not only of lipid, but also of carbohydrate. The present experiments were designed to investigate further the actions of conjugated and unconjugated bile salts on glucose metabolism. These studies have been carried out with slices of hamster small intestine. In addition, because of some disagreement in the literature concerning the utilization of glycerol in the intestine $(7,8)$, the metabolism of glucose and glycerol by hamster intestinal mucosa has been compared.

\section{EXPERIMENTAL PROCEDURE}

Materials. Male golden hamsters ${ }^{1}$ weighing 100 to $120 \mathrm{~g}$ were used in all experiments. Glucose-1-C $\mathrm{C}^{14}$ and glucose-6-C ${ }^{14} 2$ were checked for purity on Dowex columns. Batches of glucose- $\mathrm{C}^{14}$ with more than $0.5 \%$ im-

* This work was supported in part by U. S. Public Health Service grant A-3014 from the National Institutes of Health, Bethesda, Md.

$\dagger$ Present address: Department of Medicine, St. Luke's Hospital, New York, N. Y.

1 Charles River Laboratories, Boston, Mass.

2 New England Nuclear Corporation, Boston, Mass. purities were not used. In uniformly labeled glycerol- $\mathrm{C}^{14}, 2$ no contamination was detected by means of paper chromatography in two solvent systems $(9,10)$. Column chromatography was performed with Dowex 1, 20-50 mesh, which had been converted to the carbonate form by repeated washing with $10 \mathrm{vol}$ of $1 \mathrm{~N}$ sodium carbonate and subsequent washing with excess water just before use. Purified sodium taurocholate 3 and sodium glycocholate 3 were checked for purity by paper chromatography by a modification of the method of Beyreder and Rettenbacher-Däubner (11). Cholic acid,4 Tween 80,5 and digitonin 4 were obtained from manufacturers. Pure lysolecithin was a gift of Dr. Alan Hoffman. Hyamine was prepared by a modification of the method of Passman, Radin, and Cooper (12).

Methods for the measurement of radioactivity. Measurements of radioactivity were made with a Packard Tri-Carb liquid scintillation spectrometer. The solution prepared for counting substances in organic solvents or hyamine contained $8 \mathrm{ml}$ of toluene with $0.01 \% p$-bis2(5-phenyloxazolyl)-benzene and $0.3 \% \quad 2,5$-diphenyloxazole, and $3 \mathrm{ml}$ of absolute ethanol. For counting aqueous materials, $15 \mathrm{ml}$ of a solution of $p$-dioxane containing $5 \%$ naphthalene, $0.05 \%$-bis-2(5-phenyloxazolyl)benzene, $0.7 \%$ 2,5-diphenyloxazole, and $13.3 \%$ absolute ethanol was used. Appropriate corrections were made for differences in relative counting efficiencies of the two solutions.

Preparation of intestinal slices and incubation procedure. Animals were fasted for 72 hours in order to deplete the endogenous glycogen content of the intestinal mucosa (13). Preliminary experiments showed that this period of fasting was unaccompanied by any significant change in the utilization of glucose by intestinal slices. The animals were killed by a blow on the head, the small intestine was rapidly removed, and the contents washed out with cold saline. The intestine was then inverted on a chilled glass rod by the technique of Wilson and Wiseman (14), the duodenum discarded, and cylindrical, consecutive slices of upper intestine were prepared, each weighing approximately $15 \mathrm{mg}$. Four animals were usually sacrificed to provide slices for one set of experiments. One slice from each animal, chosen randomly, was blotted on filter paper and placed in

${ }^{3}$ Organon, Inc., Orange, N. J.

4 Eastman Kodak, Rochester, N. Y.

5 Polyoxyethylene sorbitan monoleate, Atlas Powder Company, Wilmington, Del. 
weighed, 25-ml Erlenmeyer flasks having a center well. These flasks contained $3 \mathrm{ml}$ of the incubation medium and $0.25 \mathrm{ml}$ of a solution of bile salts or other substances to be tested. The incubation medium consisted of KrebsRinger bicarbonate buffer modified so that the glucose concentration was $50 \mathrm{mg}$ per $100 \mathrm{ml}$ and the calcium concentration 1.3 moles per $\mathrm{L}$. This medium was treated with $95 \% \mathrm{O}_{2}$ ad $5 \% \mathrm{CO}_{2}$ shortly before use and at that time approximately $1 \mu \mathrm{c}$ of either $\mathrm{C}^{14}$-labeled glucose or $\mathrm{C}^{14}$-labeled glycerol was added.

After the addition of the slices to the flasks, they were reweighed to obtain the weight of the intestinal tissue. The flasks were then treated with $95 \% \quad \mathrm{O}_{2}$ and $5 \% \mathrm{CO}_{2}$ and capped with serum stoppers. Incubations were performed in a Dubnoff shaking incubator for 30 minutes at $37^{\circ}$.C. The reaction was stopped by the injection of $0.1 \mathrm{ml}$ of $80 \%$ trichloroacetic acid through the rubber caps into the outer well. All experiments were performed in duplicate. Paper chromatographic analysis of the bile salts remaining in the medium after incubation showed no change in $R_{f}$, and no additional spots appeared.

From preliminary experiments with glucose concentrations ranging from 25 to $100 \mathrm{mg}$ per $100 \mathrm{ml}$, it was determined that $50 \mathrm{mg}$ per $100 \mathrm{ml} \cdot(2.8 \mu$ moles per $\mathrm{ml})$ was optimal for our purposes. Higher glucose concentrations yielded such small differences after incubation that they were difficult to quantitate accurately, and lower concentrations resulted in a lower total glucose utilization. In the glucose studies reported below, a total of $9 \mu$ moles of glucose were present in the medium of each flask. When incubations were attempted at $25^{\circ}$ instead of $37^{\circ} \mathrm{C}$, glucose utilization was reduced $50 \%$. It was also shown that the rate of glucose utilization per milligram of tissue was quite constant for a period of 30 minutes when slices weighing between 70 and $150 \mathrm{mg}$ were used. No histological evidence of damage to the tissue was found unless otherwise noted in the text.

Estimation of $\mathrm{C}^{14} \mathrm{O}_{2}$ liberated. One $\mathrm{ml}$ of hyamine was injected into the center well of the Erlenmeyer flasks at the end of the incubation, and the $\mathrm{C}^{14} \mathrm{O}_{2}$ liberated by acidification was collected during the next 30 minutes as described previously (15). The hyamine was then pipetted into a standard $20-\mathrm{ml}$ counting vial, and the center well of the incubation flask rinsed with $10 \mathrm{ml}$ of the toluene counting solution.

Estimation of lipid radioactivity. The tissue was removed from the incubation medium, rinsed, and homogenized in $10 \mathrm{ml}$ of chloroform-methanol $(2: 1)$ and the total lipid extracted by the method of Folch, Lees, and Sloane Stanley (16). The lower organic layer was removed, evaporated to dryness, and the lipid residue redissolved in $10 \mathrm{ml}$ of petroleum ether. After washing three times with isotonic saline, the petroleum ether was reduced to about $1 \mathrm{ml}$ by a stream of air. To the petroleum ether was added $10 \mathrm{ml}$ of the toluene counting solution, and the $\mathrm{C}^{14}$ activity was assayed.

In some experiments, a sample of the petroleum ether fraction was evaporated to dryness and saponified with
$0.5 \mathrm{~N}$ alcoholic $\mathrm{KOH}$ for 45 minutes at $80^{\circ} \mathrm{C}$. After acidification, the liberated fatty acids were extracted with petroleum ether and counted as above. Alkaline hydrolysis showed that 92 to $97 \%$ of the $\mathrm{C}^{14}$ was present in the glycerol moiety.

Estimation of $C^{\mathbf{1 4}}$ products in the incubation medium. The incubation medium was separated into glucose- and lactate-containing fractions by column chromatography. After neutralization ( $\mathrm{pH} 8$ to 9 , phenolphthalein), the medium was added to a Dowex 1 carbonate column, and the glucose washed off the column with exactly $100 \mathrm{ml}$ of water. One hundred $\mathrm{ml}$ of $0.2 \mathrm{~N} \mathrm{HCl}$ was then added to the column. The first $20 \mathrm{ml}$ of the eluate was discarded, and the lactate-containing fraction was collected in the subsequent $80 \mathrm{ml}$. Duplicate 1- $\mathrm{ml}$ samples of each fraction were then added to the dioxane counting solution, and the $\mathrm{C}^{14}$ was assayed.

Dowex 1 carbonate was chosen for column chromatography because preliminary experiments with chloride and other resin forms indicated that over $1 \%$ of the glucose was eluted along with the lactate-containing fraction and thus was a major contaminant in experiments where glucose utilization was low. On the other hand, with Dowex 1 carbonate, no glucose remained on the column after washing with $100 \mathrm{ml}$ of water. Furthermore, analysis of the initial eluate by paper chromatography revealed no glycerol- $\mathrm{C}^{14}$ to be present. The lactate-containing fraction was analyzed chemically and found to be free of glucose, but did contain approximately $3 \%$ ketoacids (17) and 5\% phosphorylated intermediates (18). Although lactate formation was not measured chemically, analysis of the lactate-containing fraction revealed that the presence of bile salts did not alter the percentage of the nonlactate- $\mathrm{C}^{14}$ components in this fraction. Therefore, the changes in the lactate-containing fraction have been considered to reflect predominantly alterations in lactic acid- $\mathrm{C}^{14}$.

For controls, the medium alone was incubated for 30 minutes, and the intestinal slices were added after acidification. Glucose utilization was estimated by calculation of the glucose disappearance between the control and experimental flasks, and also by summation of the measured, isotopically labeled products. The latter method was found to be the most reproducible, and was used to calculate the results presented. Although $\mathrm{C}^{14}$ appeared in other metabolites, these represented an insignificant percentage of total glucose utilization. In some preliminary experiments, glucose utilization was estimated by measurement of the disappearance of glucose from the incubation medium using glucose oxidase. Because of the small changes in glucose concentration, this enzymatic method was found to be inaccurate.

The results that follow are all expressed per $100 \mathrm{mg}$ of wet tissue.

\section{RESULTS}

Metabolism of glucose by slices of small intestine in the absence of bile salts. When hamster jejunal slices were incubated in the absence of 
TABLE I

The effect of bile salts on glucose utilization by slices of hamster small intestine*

\begin{tabular}{|c|c|c|c|}
\hline Bile salt & $\begin{array}{l}\text { No. of } \\
\text { exp'ts }\end{array}$ & $\begin{array}{c}\text { Glucose utilization } \dagger \\
\text { (range) }\end{array}$ & Changet \\
\hline None & 10 & $\begin{array}{c}\text { umoles } / 100 \mathrm{mg} \text { tissue } \\
0.54 \\
(0.415-0.678)\end{array}$ & $\%$ \\
\hline $\begin{array}{l}\text { Sodium taurocholate } \\
\quad(20 \mu \text { moles per } \mathrm{ml})\end{array}$ & 6 & $\begin{array}{c}0.63 \\
(0.51-0.73)\end{array}$ & +14 \\
\hline $\begin{array}{l}\text { Sodium glycocholate } \\
(20 \mu \text { moles per } \mathrm{ml})\end{array}$ & 5 & $\begin{array}{c}1.10 \\
(0.96-1.35)\end{array}$ & +102 \\
\hline $\begin{array}{l}\text { Sodium cholate } \\
(10 \mu \text { moles per } \mathrm{ml})\end{array}$ & 4 & $\begin{array}{c}1: 22 \\
(1.06-1.35)\end{array}$ & +130 \\
\hline
\end{tabular}

* Each incubation flask contained $3.25 \mathrm{ml}$ of modified Krebs-Ringer bicarbonate buffer, $2.8 \mu$ moles of glucose$1-\mathrm{C}^{14}$ or glucose-6-C $\mathrm{C}^{14}$ per $\mathrm{ml}$ (specific activity, $0.11 \mu \mathrm{c}$ per $\mu$ mole), and 70 to $150 \mathrm{mg}$ of intestinal slices. Incubation was at $37^{\circ} \mathrm{C}$ for 30 minutes.

† Each experiment consisted of 4 incubation flasks, 2 containing glucose-1-C $\mathrm{C}^{14}$ and 2 , glucose-6-C ${ }^{14}$, from which the individual means were calculated. The range is given in parentheses.

I Because of the variation in glucose utilization, the percentage of change with bile salts was based on control experiments without bile salts performed at the same time.

bile salts, glucose utilization was found to range between 0.42 and $0.68 \mu$ moles per $100 \mathrm{mg}$ of tissue, with a mean of $0.54 \mu$ moles (Table I). As seen in Table II, $25 \%$ of glucose- $1-\mathrm{C}^{14}$ and $17.6 \%$ of glucose-6- $\mathrm{C}^{14}$ appeared as $\mathrm{C}^{14} \mathrm{O}_{2}$, the $\mathrm{C}-1$ : $\mathrm{C}-6$ ratio being 1.52 . The tissue lipids contained an average of $1.6 \%$ of the glucose carbon utilized; the difference between the radioactivity appearing from $\mathrm{C}-1$ and $\dot{\mathrm{C}}-6$ of glucose was insignificant. Glucose-1- $\mathrm{C}^{14}, 73.6 \%$, and $81.7 \%$ of the glucose6-C $\mathrm{C}^{\mathbf{1 4}}$ appeared as lactic acid-C $\mathrm{C}^{\mathbf{1 4}}$.

Metabolism of glucose in the presence of conjugated bile salts. Sodium taurocholate at a con- centration of $20 \mu$ moles per $\mathrm{ml}$ altered glucose utilization only slightly above control levels, but sodium glycocholate at the same concentration increased glucose utilization by $102 \%$ (Table I). It will be noted in Table II that, in the presence of sodium glycocholate, a much greater percentage of the utilized glucose appeared as labeled lipid. With the increase in glucose utilization with sodium glycocholate taken into account, this bile salt actually led to a tenfold increase in the conversion of glucose- $\mathrm{C}^{14}$ to labeled lipid. Thus the increased labeling of the lipid fraction was not directly proportional to the increased glucose utilization. This was also strikingly demonstrated in experiments with sodium taurocholate, where a mean rise in glucose utilization above control of only $14 \%$ was associated with an increase of 3.5 times of label in the lipid fraction.

With both taurocholate and glycocholate (20 $\mu$ moles per $\mathrm{ml}$ ), the percentage of the utilized glucose appearing in $\mathrm{C}^{14} \mathrm{O}_{2}$ decreased (Table II). More $\mathrm{C}^{14} \mathrm{O}_{2}$ was produced from glucose-1-C $\mathrm{C}^{14}$ than from glucose- $6-C^{14}$, and the $C-1: C-6$ ratio was significantly increased above control values. No changes in lactic acid- $\mathrm{C}^{14}$ production were observed with taurocholate. In the experiments with sodium glycocholate, the percentage of glucose-1- $\mathrm{C}^{14}$ converted to lactic acid- $\mathrm{C}^{14}$ fell slightly; however, because of the greater increase in total glucose utilization (Table I), the total amount of lactic acid- $\mathrm{C}^{14}$ and $\mathrm{C}^{14} \mathrm{O}_{2}$ produced was considerably increased.

Effect of concentration of conjugated bile salts on glucose metabolism. Sodium taurocholate had little effect on glucose utilization up to a bile salt

TABLE II

The effect of bile salts on the conversion of glucose- $C^{\mathbf{1 4}}$ to labeled $\mathrm{CO}_{2}$, lactate, and lipid by slices of hamster small intestine*

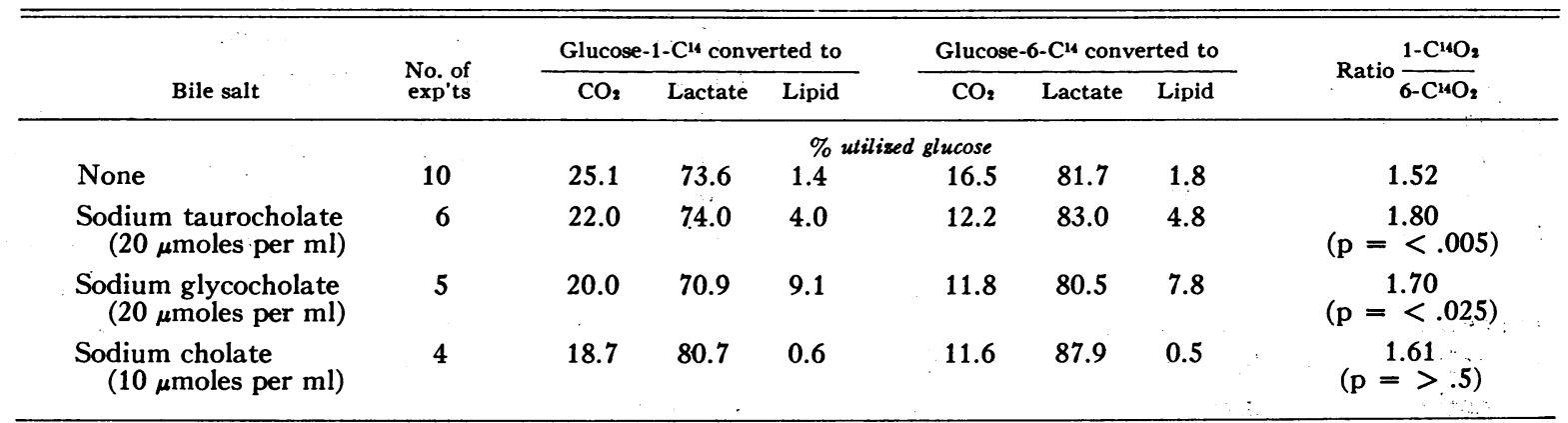

* The experiments from which these data are calculated are the same as in Table I. 

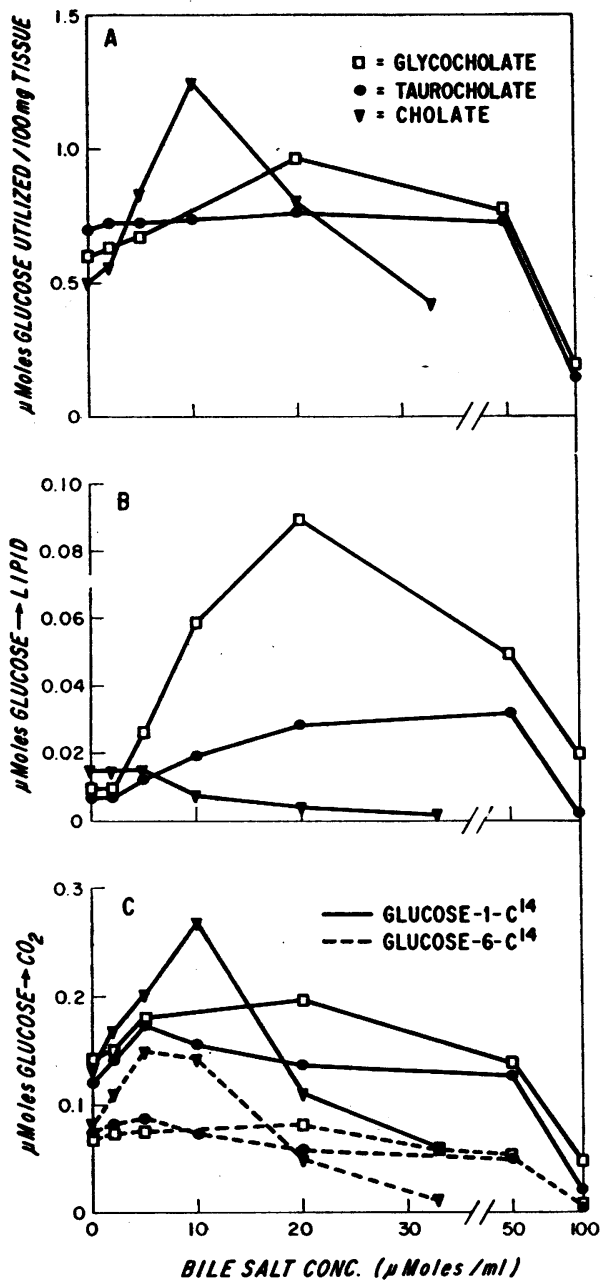

Fig. 1. EFfect of varying concentrations of BILE SALTS ON GLUCOSE UTILIZATION AND METABOLISM BY SLICES OF HAMSTER SMALl INTESTINE. A. Effect of bile salts on glucose-C ${ }^{14}$ utilization. B. Effect of bile salts on the incorporation of label into lipid from glucose- $\mathrm{C}^{\mathbf{1 4}}$. C. Effect of bile salts on the conversion of glucose-1-C ${ }^{14}$ and glucose-6- $\mathrm{C}^{14}$ to $\mathrm{C}^{14} \mathrm{O}_{2}$. Incubation flasks contained $3.25 \mathrm{ml}$ of modified Krebs-Ringer bicarbonate buffer, intestinal slices totaling 70 to $150 \mathrm{mg}, 2.8 \mu$ moles glucose-1-C ${ }^{14}$ or glucose-6-C ${ }^{14}$ (specific activity, 0.11 $\mu \mathrm{c}$ per $\mu \mathrm{mole})$, and bile salts at the final concentrations indicated in the figure. Incubations were at $37^{\circ} \mathrm{C}$ for 30 minutes. Results are expressed per $100 \mathrm{mg}$ of tissue. Figure shown represents mean values of 4 experiments performed in duplicate for taurocholate and glycocholate and 3 experiments in duplicate for cholate.

concentration of $50 \mu$ moles per $\mathrm{ml}$, whereas glycocholate stimulated glucose utilization consistently with a maximum at $20 \mu$ moles per $\mathrm{ml}$ (Figure 1A). Glucose utilization fell markedly in the presence of both bile salts at a concentration of $100 \mu$ moles per $\mathrm{ml}$.

The appearance of label in the lipid fraction at differing concentrations of bile salts (Figure 1B) in general followed the change in glucose utilization, but as noted before (Table II), was not directly proportional to the glucose utilized. Alkaline hydrolysis revealed that over $95 \%$ of the $\mathrm{C}^{14}$ in lipid was in the glycerol moiety.

The effect of varying concentrations of bile salts on the conversion of glucose-1-C $\mathrm{C}^{14}$ and glucose-6- $\mathrm{C}^{14}$ to $\mathrm{C}^{14} \mathrm{O}_{2}$ is shown in Figure 1C. Distinct stimulation of $\mathrm{C}^{14} \mathrm{O}_{2}$ production from glucose-1- $\mathrm{C}^{14}$ was noted even with low concentrations of conjugated bile salts. Because of the experimental variation in the absence of bile salts, additional experiments were performed that repeatedly confirmed this observation. There was, however, no stimulation of $\mathrm{C}^{14} \mathrm{O}_{2}$ formation from glucose-6$\mathrm{C}^{14} \cdot \mathrm{C}^{14} \mathrm{O}_{2}$ production from glucose- $\mathrm{C}^{14}$ decreased in the presence of bile salt concentrations above $20 \mu$ moles per $\mathrm{ml}$.

In general, the amount of glucose- $\mathrm{C}^{14}$ converted to lactic acid-C ${ }^{14}$ closely reflected changes in total glucose utilization. Thus, although the percentage of glucose-C $\mathrm{C}^{14}$ converted to lactic acid-C ${ }^{14}$ remained unchanged, when total glucose utilization increased, the total production of labeled lactic acid also increased. As seen in Table II, the amount of lactic acid-C ${ }^{14}$ produced from glucose$1-\mathrm{C}^{14}$ and glucose-6-C $\mathrm{C}^{14}$ was inversely proportional to the $\mathrm{C}^{14} \mathrm{O}_{2}$ produced from these substrates.

Metabolism of glucose in the presence of unconjugated bile salts. It was previously shown (6) that conjugated bile salts behave differently from their unconjugated derivatives and that the latter may, under some conditions, actually exert a destructive effect on the intestinal mucosa. In our system, no histological evidence of damage was found with low concentrations of sodium cholate (less than $20 \mu$ moles per $\mathrm{ml}$ ), but sodium deoxycholate was deleterious to the mucosa, and was therefore not used. Sodium cholate, at a concentration of $10 \mu$ moles per $\mathrm{ml}$ (Table I) and at all concentrations below $20 \mu$ moles per ml (Figure 1A), produced striking stimulation of glucose utilization. In addition, although some decrease in the percentage of utilized glucose converted to $\mathrm{C}^{14} \mathrm{O}_{2}$ occurred (Table II) because of the great in- 
crease in glucose utilization, the total amount of $\mathrm{C}^{14} \mathrm{O}_{2}$ produced was considerably increased (Figure 1C). Different results were seen with higher concentrations of cholate in that both glucose utilization and $\mathrm{C}^{14} \mathrm{O}_{2}$ production fell markedly.

In contrast to the observations with conjugated bile salts, the appearance of $\mathrm{C}^{14}$ in lipid never increased (Figure 1B), and in fact was negligible at $33 \mu$ moles sodium cholate per $\mathrm{ml}$. At this cholate concentration, glucose utilization was still appreciable and $\mathrm{C}^{14} \mathrm{O}_{2}$ production significant.

In previous studies from this laboratory (19), it was shown that palmitate esterification by the intestinal mucosa ceased in the absence of oxygen. Experiments were therefore performed in an atmosphere of $95 \% \mathrm{~N}_{2}$ and $5 \% \mathrm{CO}_{2}$ to test if the effects of sodium cholate on glucose metabolism by intestinal slices were similar to those seen with anaerobiosis. A depression of glucose- $\mathrm{C}^{14}$ incorporation into lipid and an increase in lactic acid- $\mathrm{C}^{14}$ production was observed just as was noted in the presence of sodium cholate. Only a $10 \%$ rise in glucose utilization occurred, however. and there was a distinct fall in the appearance of $\mathrm{C}^{14} \mathrm{O}_{2}$. Thus the results under conditions of anaerobiosis were different from those seen with sodium cholate.

Quantitative studies of glucose metabolism by cellular constituents released into the medium during incubation. To determine whether the observed metabolic effects of bile salts were due to reactions that occurred within the intestinal slices. or to activity of intracellular enzymes released into the medium, experiments were performed in which intestinal slices were first preincubated in the medium with or without bile salts. After this, the slices were removed, and the medium remaining was then incubated with glucose- $\mathrm{C}^{14}$ for 30 minutes. It is seen in Table III that in the absence of bile salts, glucose utilization by the medium prepared in this manner was only $6 \%$ of that by the slice preparation incubated in the usual manner. Furthermore, while glycocholate stimulated glucose utilization and glucose oxidation by the slices as in previous experiments, glucose utilization and oxidation in the medium were further depressed in the presence of the bile salt. It would appear, therefore, that the changes in glucose metabolism observed by incubating intestinal slices were due to effects on metabolic reactions
TABLE III

Comparison of glucose-1-C $C^{\mathbf{1 4}}$ metabolism by hamster small intestinal slices and by medium after preincubation with slices, in the presence and absence of bile salts

\begin{tabular}{|c|c|c|c|c|c|}
\hline \multirow[b]{2}{*}{ Bile salt } & \multirow[b]{2}{*}{ Incubation* } & \multirow[b]{2}{*}{$\begin{array}{l}\text { Glucose } \\
\text { utilized }\end{array}$} & \multicolumn{3}{|c|}{$\begin{array}{l}\text { Distribution } \\
\text { of } \mathrm{C}^{14} \text { in }\end{array}$} \\
\hline & & & $\mathrm{CO}_{2}$ & $\begin{array}{l}\text { Lac- } \\
\text { tate }\end{array}$ & Lipid \\
\hline & & $\begin{array}{c}\text { ymoles/ } \\
\text { lOO mg } \\
\text { tissue }\end{array}$ & \multicolumn{3}{|c|}{ \% utilized glucose } \\
\hline None & $\begin{array}{l}\text { Slices incubated } \\
\text { Slices preincubated } \\
\text { then medium } \\
\text { incubated }\end{array}$ & $\begin{array}{l}0.65 \\
0.04\end{array}$ & $\begin{array}{l}30 \\
49\end{array}$ & $\begin{array}{l}68 \\
47\end{array}$ & $\begin{array}{l}2 \\
4\end{array}$ \\
\hline $\begin{array}{l}\text { Glycocholate } \\
(20 \mu \text { moles } \\
\text { per } \mathrm{ml})\end{array}$ & $\begin{array}{l}\text { Slices incubated } \\
\text { Slices preincubated } \\
\text { then medium } \\
\text { incubated }\end{array}$ & $\begin{array}{l}1.31 \\
0.02\end{array}$ & $\begin{array}{r}39 \\
7\end{array}$ & $\begin{array}{l}56 \\
88\end{array}$ & $\begin{array}{l}5 \\
5\end{array}$ \\
\hline
\end{tabular}

* In preincubation experiments, intestinal slices were preincubated for 30 minutes in $3.25 \mathrm{ml}$ of modified KrebsRinger bicarbonate buffer and $2.8 \mu$ moles glucose per $\mathrm{ml}$. The slices were then removed and glucose-1-C ${ }^{14}$ added (final specific activity, $0.11 \mu \mathrm{c}$ per $\mu$ mole), and incubation was carried out for 30 minutes. In regular incubations, slices were incubated in the same system for 30 minutes with glucose-1-C $\mathrm{C}^{14}$. All incubations were at $37^{\circ} \mathrm{C}$. Data shown represent mean values of 4 experiments performed in duplicate.

occurring within the cell and not to effects on enzymes that had leaked into the medium.

The effect of other surface-active agents on glucose metabolism. Steroid and nonsteroid surfaceactive substances were tested in order to compare their actions with those of bile salts. Tween 80 was studied at concentrations between 1.4 and $14 \mu$ moles per ml. ${ }^{6}$ At these concentrations, no gross changes in histological structure could be detected. Figure 2A demonstrates that glucose utilization was stimulated progressively as the Tween 80 concentration increased; at $14 \mu$ moles per ml, glucose utilization was increased by $250 \%$. This great rise in glucose utilization was primarily due to an increased lactic acid- $\mathrm{C}^{14}$ production. In contrast to the observations with bile salts, there was no associated change in $\mathrm{C}^{14} \mathrm{O}_{2}$ production from glucose-1- $\mathrm{C}^{14}$ despite the great increase in glucose utilization (Figure 2C). $\quad \mathrm{C}^{14} \mathrm{O}_{2}$ formation from glucose-6- $\mathrm{C}^{14}$ did increase slightly at the higher concentrations. Although the incorporation of $\mathrm{C}^{14}$ into lipid was stimulated (Figure $2 \mathrm{~B}$ ), the amount of labeled lipid produced per $\mu$ mole of glucose utilized was considerably less than with

\footnotetext{
${ }^{6}$ The molecular weight of Tween 80 was taken as $1,450(20)$.
} 
the conjugated bile salts. Thus, the metabolic effects of Tween 80 differ from those of the conjugated or unconjugated bile salts.

Lysolecithin at a concentration of $5 \mu$ moles per $\mathrm{ml}$ and digitonin at 2.5 and $20 \mu$ moles per $\mathrm{ml}$ depressed all reactions measured, and on histologic examination, there was pronounced destruction of the mucosa. In view of this, no further studies were carried out with these substances.
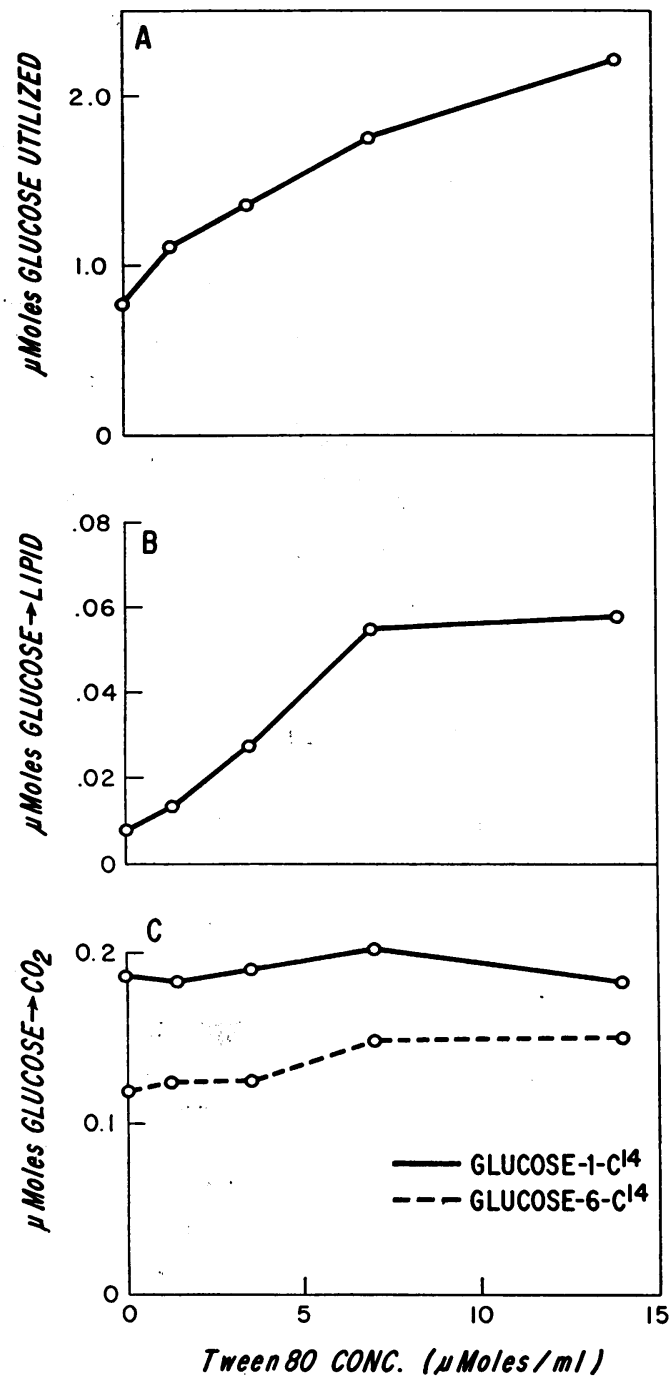

Fig. 2. EFfect of varying concentrations of TWEEN 80 ON GLUCOSE UTILIZATION AND METABOLISM BY SLICES OF HAMSTER SMALL INTESTINE. Incubation system was as described in Figure 1 . The medium contained $2.8 \mu$ moles of either glucose-1- $\mathrm{C}^{14}$ or glucose-6-C $\mathrm{C}^{14}$, and Tween 80 at the concentrations indicated. Figure shown represents mean values of 3 experiments performed in duplicate.
TABLE IV

Comparison of glycerol and glucose utilization and the effect of bile salts on the conversion of glycerol- $C^{14}$ to labeled $\mathrm{CO}_{2}$, lactate, and lipid by slices of hamster small intestine*

\begin{tabular}{|c|c|c|c|c|}
\hline \multirow[b]{2}{*}{ Addition } & \multirow{2}{*}{$\begin{array}{l}\text { Amount } \\
\text { utilized }\end{array}$} & \multicolumn{3}{|c|}{ Distribution of $\mathrm{C}^{14}$ in } \\
\hline & & $\mathrm{CO}_{2}$ & Lactate & Lipid \\
\hline & $\begin{array}{c}\mu \text { moles } / 100 \mathrm{mg} \\
\text { tissue }\end{array}$ & \multicolumn{3}{|c|}{ \% utilized substrale } \\
\hline Glycerol-C ${ }^{14}$ & 0.18 & 55 & 39 & 6 \\
\hline $\begin{array}{l}\text { Glycerol-C } C^{14} \text { plus } \\
\text { taurocholate } \\
(20 \mu \text { moles per } \mathrm{ml})\end{array}$ & 0.27 & 57 & 23 & 20 \\
\hline Glucose-1-C $C^{14}$ & 0.66 & 27 & 71 & 2 \\
\hline $\begin{array}{l}\text { Glucose-1-C } C^{14} \text { plus } \\
\text { taurocholate } \\
(20 \mu \text { moles per } \mathrm{ml})\end{array}$ & 0.73 & 21 & 73 & 6 \\
\hline
\end{tabular}

* Each incubation flask contained, in addition to the intestinal slices, $3.25 \mathrm{ml}$ of modified Krebs-Ringer bicarbonate buffer and $2.8 \mu$ moles per $\mathrm{ml}$ of either glycerol- $\mathrm{C}^{14}$ or glucose-1-C 14 (specific activity, $0.11 \mu \mathrm{c}$ per $\mu$ mole). Incubation was at $37^{\circ} \mathrm{C}$ for 30 minutes. Data shown represents mean values of 4 experiments performed in duplicate.

Comparison of glycerol and glucose metabolism. To compare glycerol and glucose metabolism, glycerol-C $\mathrm{C}^{14}$ was used instead of glucose-1-C $\mathrm{C}^{14}$. $\mathrm{C}^{14}$ appeared in $\mathrm{CO}_{2}$ and lipid, both in the presence and absence of glucose in the medium. Table IV shows the results of an experiment in which equimolar concentrations of glycerol were substituted for glucose. Although significant utilization of glycerol did occur, it was only $20 \%$ as great as the glucose utilization. In addition, a much smaller percentage of the $\mathrm{C}^{14}$ from glycerol appeared in lactic acid. As in the case of glucose metabolism, taurocholate $(20 \mu$ moles per $\mathrm{ml})$ stimulated glycerol utilization significantly (Table IV) and led to a threefold stimulation of incorporation of glycerol-C $\mathrm{C}^{14}$ into lipid. It will be seen that in the presence of taurocholate, almost as much glycerol- $\mathrm{C}^{14}$ as glucose- $\mathrm{C}^{14}$ appeared in lipid.

\section{DISCUSSION}

In previous studies from this laboratory (6), it was shown that in the intestinal mucosa conjugated bile salts stimulate palmitate- $\mathrm{C}^{\mathbf{1 4}}$ and glucose- $\mathrm{C}^{14}$ incorporation into glyceride-glycerol. These results suggested that in addition to their role in intraluminal digestion, bile salts directly influence metabolic events within the epithelial cells of the intestinal mucosa. In the studies re- 
ported here, the effects of bile salts on the intestinal metabolism of glucose- $\mathrm{C}^{14}$ have been further investigated.

The results of our experiments indicate that the effect of bile salts on glucose metabolism are not confined to changes in glucose incorporation into glyceride-glycerol. Glucose utilization was enhanced considerably in the presence of sodium glycocholate and to a small extent by taurocholate. The changes in glucose utilization were neither solely due to the diversion of the additional utilized glucose into metabolic pathways leading to glyceride-glycerol formation, nor were they directly proportional to the amount of glucose- $\mathrm{C}^{14}$ incorporated into lipid- $\mathrm{C}^{14}$. Thus at low concentrations of conjugated and unconjugated bile salts, the $\mathrm{C}^{14}$ incorporation into lipid was unchanged, although increased glucose utilization and incorporation of label into $\mathrm{CO}_{2}$ and lactic acid were observed (Figure 1). Furthermore, in the presence of glycocholate $(20 \mu$ moles per $\mathrm{ml})$, glucose utilization increased two times, but labeling of the lipid fraction increased ten times.

Since most of the $\mathrm{C}^{14}$ of glucose appearing in the glyceride-glycerol molecule was in the glycerol rather than the fatty acid fraction, the question arises whether there may have been displacement of previously unlabeled glycerol from neutral lipids (i.e., transesterification or exchange), or esterification of fatty acids present in the tissue. The latter mechanism would appear most likely, since transesterification or exchange reactions between glycerol and glycerides have thus far not been observed (21).

In the previous experiments cited (6), unconjugated bile salts were shown to suppress both palmitate esterification to triglycerides and intestinal transport of glucose. It was postulated then that the depression of palmitate esterification might be related to a decreased supply of tissue glucose. In the present experiments, however, glucose utilization, and lactic acid- $\mathrm{C}^{14}$ and $\mathrm{C}^{14} \mathrm{O}_{2}$ production by the intestine were increased in the presence of sodium cholate. This suggests that the decrease in palmitate esterification by sodium cholate is not due to a decrease of available tissue glucose, but more likely to a direct effect on fatty acid absorption or triglyceride synthesis in the mucosal cell. In the present experiments, sodium cholate inhibited glucose- $\mathrm{C}^{14}$ incorporation into mucosal lipid even without any additional lipid in the medium. Under these conditions, the endogenous fatty acids are utilized for glyceride formation. Inhibition of fatty acid esterification by unconjugated bile salts could be due to $a$ ) loss of tissue fatty acids into the medium and depression of their reabsorption, $b$ ) suppression of fatty acyl-CoA formation, or $c$ ) interference of the reaction by which $L$ - $\alpha$-glycerophosphate and two acyl-CoA fatty acids are converted to phosphatidic acid (22). Conjugated as well as unconjugated bile salts have been shown to inhibit both the formation and subsequent esterification of palmityl CoA by subcellular particles of the intestinal mucosa (23). Because of the solubilization property of bile salts, studies of fatty acid esterification in subcellular particles are difficult to interpret, and for this reason the present studies were performed with slices of small intestine.

Our data on $\mathrm{C}^{14} \mathrm{O}_{2}$ production confirm the observations of Landau and Wilson (24) that the pentose phosphate shunt is present in the hamster intestine. In addition, we observed that $\mathrm{C}^{14} \mathrm{O}_{2}$ formation from glucose-1-C $\mathrm{C}^{14}$ was stimulated at low concentrations of bile salts, while that from glucose-6-C $\mathrm{C}^{14}$ was unchanged. This suggests that bile salts can increase the amount of glucose metabolized via the pentose phosphate shunt. The glucose- $\mathrm{C}^{14}$ data, however, could also be explained by simultaneous stimulation of both the shunt and Embden-Meyerhof pathways, but without increased tricarboxylic acid cycle activity. The lack of difference in the recovery of label in lipid from glucose-1- $\mathrm{C}^{14}$ and glucose-6- $\mathrm{C}^{14}$ agrees with the latter possibility.

In comparing the effect of two conjugated bile salts, it was found that glycocholate stimulated glucose utilization, and enhanced glucose- $\mathrm{C}^{14}$ incorporation into $\mathrm{C}^{14} \mathrm{O}_{2}$ and glyceride-glycerol to a far greater extent than taurocholate. The reason for this difference is not clear. Hamster as well as human bile contains predominantly glycine conjugated bile salts, and glycocholate has also been shown to form micellar solutions with oleic acid more readily than taurocholate, but no difference has been noted with other lipids (3). Olson (25), however, in studying the stimulation of vitamin A cleavage in the intestine by bile salts observed no significant difference between a number of taurine and glycine conjugates. 
The in vitro demonstration of glycerol- $\mathrm{C}^{14}$ metabolism by the intestinal mucosa is consistent with recent in vivo demonstrations of gylcerol incorporation into lymph triglyceride in animals $(26)$ and in man (27). The demonstration of glycerol utilization and incorporation into intestinal triglyceride raises the question of the metabolic steps involved, since earlier reports $(7,28)$ suggested that the intestinal mucosa lacks a glycerokinase. Recent experiments in this laboratory, however, indicate that such an enzyme is indeed present in the intestinal mucosa (29), although its activity is much lower than in the liver (30).

In order to ascertain if the metabolic changes observed with bile salts were due only to their surface active properties, studies were performed with other surface active agents. Digitonin and lysolecithin were found to be destructive to the intestinal mucosa. The damaging effect of lysolecithin at a concentration of $5 \mu$ moles per $\mathrm{ml}$ is of interest in view of the recent demonstration that phospholipids are secreted in large quantities into the intestinal lumen from the biliary tract (31). Tween 80 greatly stimulated glucose utilization and glycolysis, but in contrast to bile salts, failed to enhance glucose oxidation. This surface-acting agent had previously been shown to enhance fatty acid esterification only slightly (6), and in the present experiments stimulated glucose- $\mathrm{C}^{14}$ incorporation into triglycerides less than bile salts. Such stimulation of esterification of fatty acids, however, contrasts with the observations of Mahadevan, Murthy, Krishnamurthy, and Ganguly (32), who found distinct inhibition of vitamin A esterification in rat intestinal homogenates in the presence of Tween 80 . We considered the possibility that part of the Tween 80 might have been absorbed and subsequently hydrolyzed to liberate oleic acid in the intestinal mucosa, and that the results noted were in fact caused by this fatty acid. The effects, however, of oleic acid absorption on intestinal glucose metabolism (33) are quite different from those with Tween 80. It is of interest that Tween 80 is frequently used to solubilize lipids for in vitro experiments. In view of the pronounced metabolic effects of this agent, it would seem undesirable to use it in experiments where the function of the intestinal mucosa is being investigated.

Some of the previously noted effects of conju- gated bile salts on intestinal mucosal function $(6$, 34,35 ), although most likely intracellular, could also have been secondary to actions on the cell surface. Our data clearly demonstrate that the changes in glucose metabolism observed resulted from the action of the bile salts on the intact intestinal slice and not on cellular constituents released into the medium during incubation. In fact, bile salts inhibited not only glucose utilization, but glucose oxidation in the medium. Thus the effects of bile salts must have resulted from actions on the cellular surface or within the cell.

The present experiments would suggest that the actions of bile salts are more likely to be due to effects within the cell rather than on the surface alone. This is demonstrated by the fact that bile salts affect glucose utilization and incorporation of glucose- $\mathrm{C}^{14}$ into various metabolites differently. Sodium cholate, for example, inhibited the incorporation of glucose- $\mathrm{C}^{14}$ into glyceride-glycerol. although glycolysis and $\mathrm{C}^{14} \mathrm{O}_{2}$ production were stimulated. On the other hand, with glycocholate and taurocholate, all reactions were enhanced. Furthermore, in the presence of the conjugated bile salts, $\mathrm{C}^{14} \mathrm{O}_{2}$ production from glucose-1-C $\mathrm{C}^{14}$ and glucose-6- $\mathrm{C}^{14}$ were not equally affected, so that the $\mathrm{C}-1: \mathrm{C}-6$ ratio varied even at the low bile salt concentrations present in the fasting human intestine. In addition, clearly different results were noted with Tween 80 , a surface-active detergent, as compared to both conjugated and unconjugated bile salts. Finally, it is known that bile salts are transported into the cell under the conditions of our experiments (36), and thus it is reasonable for them to exert intracellular effects. The mechanisms by which these intracellular actions may be mediated, however, require further elucidation.

\section{SUM M ARY}

Bile salts have been shown to influence the utilization and metabolism of glucose-1- $\mathrm{C}^{14}$ and glucose- $6-\mathrm{C}^{14}$ by slices of hamster small intestine in vitro. 1) Glucose utilization was considerably increased in the presence of sodium glycocholate and sodium cholate, although only slightly with sodium taurocholate. These effects were noted with bile salt concentrations that occur physiologically in the lumen of the small intestine. 2) 
Glucose- $\mathrm{C}^{14}$ incorporation into glyceride-glycerol was stimulated by conjugated bile salts and was not related to changes in total glucose utilization. On the other hand, in the presence of sodium cholate, glucose- $\mathrm{C}^{14}$ incorporation into lipid was depressed despite an increased glucose utilization. 3) $\mathrm{C}^{14} \mathrm{O}_{2}$ production increased as glucose utilization rose, but it was not proportional to the increased glucose utilization. The appearance of $\mathrm{C}^{14} \mathrm{O}_{2}$ from glucose-1-C ${ }^{14}$ was stimulated at low concentrations of conjugated bile salts, while $\mathrm{C}^{14} \mathrm{O}_{2}$ production from glucose-6- $\mathrm{C}^{14}$ was unchanged. Sodium cholate stimulated $\mathrm{C}^{14} \mathrm{O}_{2}$ production from both glucose-1-C $\mathrm{C}^{14}$ and glucose-6-C $\mathrm{C}^{14}$. 4) Lactic acid- $\mathrm{C}^{14}$ formation was a prominent feature of aerobic glucose utilization in hamster jejunum. 5) The effects of bile salts on glucose$\mathrm{C}^{14}$ metabolism differed qualitatively and quantitatively from those produced by Tween 80 , a nonionic surface-active agent.

Significant glycerol- $\mathrm{C}^{14}$ incorporation into $\mathrm{mu}$ cosal lipids was demonstrated in hamster intestinal slices, and this was also stimulated by sodium taurocholate. In addition, $\mathrm{C}^{14} \mathrm{O}_{2}$ and lactic acid$\mathrm{C}^{14}$ production from glycerol-C ${ }^{14}$ were observed.

The results reported provide further evidence that bile salts influence metabolic reactions occurring within the cells of the small intestinal mucosa.

\section{REFERENCES}

1. Verzar, F., and E. J. McDougall. Absorption from the Intestine. New York, Longmans, Green, 1936.

2. Borgström, B. On the mechanism of the hydrolysis of glycerides by pancreatic lipase. Acta chem. scand. 1953, 7, 557.

3. Hofmann, A. F., and B. Borgström. Physicochemical state of lipids in intestinal content during their digestion and absorption. Fed. Proc. 1962, 21, 43.

4. Olson, J. A. The conversion of radioactive $\beta$-carotene into vitamin $\mathrm{A}$ by rat intestine in vivo. $\mathrm{J}$. biol. Chem. 1961, 236, 349.

5. Smith, A. L., and C. R. Treadwell. Effect of the bile acids and other factors on cholesterol uptake by inverted intestinal sacs. Amer. J. Physiol. 1958, 195, 773.

6. Dawson, A. M., and K. J. Isselbacher. Studies on lipid metabolism in the small intestine with observations on the role of bile salts. $\mathrm{J}$. clin. Invest. 1960, 39, 730.

7. Buell, G. C., and R. Reiser. Glyceride-glycerol precursors in the intestinal mucosa. J. biol. Chem. 1959, 234, 217.
8. Buchs, A., and P. Favarger. Recherches sur le métabolisme du glycérol lipidique. Helv. physiol. pharmacol. Acta 1959, 17, 365.

9. Mortimer, D. C. Paper chromatographic separation of some biologically important phosphate esters. Canad. J. Chem. 1952, 30, 653.

10. Margolis, S., and M. Vaughan. $\alpha$-Glycerophosphate synthesis and breakdown in homogenates of adipose tissue. J. biol. Chem. 1962, 237, 44.

11. Beyreder, J., and H. Rettenbacher-Däubner. Separation of some bile acids by means of paper chromatography. Mschr. 1953, 84, 99.

12. Passmann, J. M., N. S. Radin, and J. A. D. Cooper. Liquid scintillation technique for measuring carbon-14-dioxide activity. Analyt. Chem. 1956, 28, 484.

13. Crane, R. K., and P. Mandelstam. The active transport of sugars by various preparations of hamster intestine. Biochim. biophys. Acta (Amst.) 1960, 45, 460 .

14. Wilson, T. H., and G. Wiseman. The use of sacs of everted small intestine for the study of the transference of substances from the mucosal to the serosal surface. J. Physiol. 1954, 123, 116.

15. Isselbacher, K. J., and E. A. McCarthy. The influence of pyridine nucleotides on galactose-1-C $\mathrm{C}^{14}$ oxidation to $\mathrm{C}^{14} \mathrm{O}_{2}$ in vitro. Biochem. biophys. Res. Commun. 1959, 1, 49.

16. Folch, J., M. Lees, and G. H. Sloane Stanley. A simple method for the isolation and purification of total lipides from animal tissues. J. biol. Chem. 1957, 226, 497.

17. Koepsell, H. J., and E. S. Sharpe. Microdetermination of pyruvic and $\alpha$-ketoglutaric acids. Arch. Biochem. 1952, 38, 443.

18. LePage, G. A. Methods for the analysis of phosphorylated intermediates in Manometric Techniques, W. W. Umbreit, R. H. Burris, and J. F. Stauffer, Eds. Minneapolis, Burgess, 1957, p. 269.

19. Dawson, A. M., and K. J Isselbacher. The esterification of palmitate-1-C $\mathrm{C}^{14}$ by homogenates of intestinal mucosa. J. clin. Invest. 1960, 39, 150.

20. Zachman, R. D., and Olson, J. A. A comparison of retinene reductase and alcohol dehydrogenase of rat liver. J. biol. Chem. 1961, 236, 2309.

21. Isselbacher, $\mathrm{K}$. J. Unpublished observations.

22. Kennedy, E. P. Metabolism of lipides. Ann. Rev. Biochem. 1957, 26, 119.

23. Senior, J. R., and K. J. Isselbacher. Unpublished observations.

24. Landau, B. R., and T. H. Wilson. The role of phosphorylation in glucose absorption from the intestine of the golden hamster. J. biol. Chem. 1959, 234, 749.

25. Olson, J. A. The effect of free and conjugated bile acids on $\beta$-carotene absorption and cleavage in the rat intestine. Fed. Proc. 1962, 21, 473.

26. Saunders, D. R., and A. M. Dawson. Studies on the metabolism of glycerol by the small intestine in vitro and in vivo. Biochem. J. 1962, 82, 477. 
27. Holt, P. R. Incorporation of $\mathrm{C}^{14}$ labeled glycerol into urinary lipids in a patient with chyluria. Clin. Res. 1962, 10, 228.

28. Wieland, O., and M. Suyter. Glycerokinase: Isolierung und Eigenschaften des Enzyms. Biochem. Z. 1957, 329, 320.

29. Haessler, H. A., and K. J. Isselbacher. Glycerol metabolism in the intestinal mucosa and its role in fat absorption (abstract). Amer. J. Dis. Child. 1962, 104, 543.

30. Haessler, H. A., and K. J. Isselbacher. The metabolism of glycerol by the intestinal mucosa. Biochim. biophys. Acta. (Amst.). In press.

31. Turner, D. A. Lipids of bile and intestinal synthesis of triglycerides. Fed. Proc. 1962, 21, suppl. $2,25$.
32. Mahadevan, S., S. K. Murthy, S. Krishnamurthy, and J. Ganguly. Studies on vitamin A esterase. 4. The hydrolysis and synthesis of vitamin A esters by rat intestinal mucosae. Biochem. J. 1961, 79, 416.

33. Holt, P. R., H. A. Haessler, and K. J. Isselbacher. The effect of fatty acid and monoglyceride absorption on glucose- $\mathrm{C}^{14}$ metabolism by intestinal mucosa. In preparation.

34. Bergström, S., M. Rottenberg, and J. Sjövall. Utber den Stoffwechsel der Cholsaüre und Desoxycholsaüre in der Ratte. Hoppe-Seylers Z. physiol. Chem. 1953, 295, 278.

35. Borgström, B. On the mechanism of intestinal fat absorption. Acta physiol. scand. 1953, 28, 278.

36. Holt, P. R. Unpublished observations. 